\title{
Dry mass loss of different moisture content canola at different temperatures
}

\author{
Fuji Jian ${ }^{1,}$, Rajendran Vignesh ${ }^{1}$, and Liam Carlin ${ }^{1}$ \\ ${ }^{I}$ Department of Biosystems Engineering, University of Manitoba, Winnipeg, MB, R3T 5 V6 Canada \\ ${ }^{*}$ Corresponding Author: fuji.jian@umanitoba.ca
}

\begin{abstract}
Dry mass loss (DML) of Sound canola and Mouldy canola (sound + mouldy canola) was measured at 25,30 , and $35^{\circ} \mathrm{C}$ over 14 weeks by weighing $10 \mathrm{~kg}$ samples every 2 week. The moisture content of the canola was $10,12.5$, and $15.0 \%$ (wet basis). The relationship was quantified among the DML measured gravimetrically, germination decrease rate (GDR), and decrease in the percentage of test weight (PTW). The measured DML was also compared with the DML estimated from respired $\mathrm{CO}_{2}$. The measured DML increased as germination and test weight decreased, and the Spearmen Rank Order correlation between DML and germination or between DML and PTW was greater than 0.58 in 18 of 24 cases. The GDR of mouldy canola was significantly higher than that of Sound canola except at $15 \%$ moisture content and $35^{\circ} \mathrm{C}$. A decrease of germination and/or PTW could be used to estimate roughly the DML trend but did not predict the DML value with high accuracy. There was no significant difference between the measuredand estimated-DML. Measuring the mass loss or $\mathrm{CO}_{2}$ production roughly estimated DML but using DML to evaluate grain quality was unreliable.
\end{abstract}

\section{KEYWORDS}

Dry mass loss, sound canola, mouldy canola, germination

\section{RÉSUMÉ}

La perte de masse sèche du canola sain et du canola moisi (canola sain + canola moisi) a été mesurée à 25,30 et $35^{\circ} \mathrm{C}$ pendant 14 semaines en pesant des échantillons de $10 \mathrm{~kg}$ toutes les 2 semaines. La teneur en eau du canola était de 10, 12,5 et 15,0\% (base humide). La relation, entre la perte de masse sèche mesurée par gravimétrie, le taux de diminution de la germination et la diminution du pourcentage du poids spécifique, a été quantifiée. La perte de masse sèche mesurée a également été comparée à la perte de masse sèche estimée à partir du $\mathrm{CO}_{2}$ respiré. La perte de masse sèche mesurée a augmenté à mesure que la germination et le poids spécifique diminuaient, et la corrélation de Spearmen entre la perte de masse sèche et la germination ou entre la perte de masse sèche et le pourcentage du poids était supérieure à 0,58 dans 18 cas sur 24 . Le taux de diminution de la germination du canola moisi était significativement plus élevé que celui du canola sain, sauf à une teneur en eau de $15 \%$ et à $35^{\circ} \mathrm{C}$. La diminution de la germination ou du pourcentage du poids spécifique a pu être utilisée pour estimer approximativement la tendance de la perte de masse sèche, mais n'a pas permis de prédire la valeur de la perte de masse sèche avec une grande précision. Il n'y avait pas de différence significative entre la perte de masse sèche mesurée et estimée. La mesure de la perte de masse ou de la production de $\mathrm{CO}_{2}$ a permis d'estimer approximativement la perte de masse sèche, mais l'utilisation de cette perte de masse pour évaluer la qualité du grain n'était pas fiable.

\section{MOTS CLÉS}

Perte de masse sèche, canola sain, canola moisi, germination.

\section{CITATION}

Jian, F., R. Vignesh and L. Carlin. 2020. Dry mass loss of different moisture content canola at different temperatures. Canadian Biosystems Engineering/Le génie des biosystèmes au Canada 62: 3.1-3.10. https://doi.org/10.7451/CBE.2020.62.3.1 


\section{INTRODUCTION}

Significant losses of stored grain (cereal grains, pulse, and oilseeds) may occur if the grain is not stored under proper conditions. About one-third of the annual global food production is lost each year before reaching the final consumers (FAO 2011). During postharvest handling and storage, the loss of grain is estimated at $8 \%$ in Sub-Saharan Africa, 7\% in Southeast Asia, and 4\% in Latin America (FAO 2011). The main reasons causing this loss during storage are mould infection, insect infestation, and/or spoilage of the grain itself at high temperatures and moisture contents. The recommended safe storage moisture content of canola is $8 \%$ (wet basis) (Sun et al. 2014). Canola with higher than $10 \%$ moisture content at higher than $25^{\circ} \mathrm{C}$ can be infected by Penicillium spp., Aspergillus glaucus group, Aspergillus candidus Link, and Alternaria alternata (Fr.) Keissler (White et al. 1982a; Sun et al. 2014). These fungal infections and multiplication can result in a dry mass loss (DML).

The parameters most used to measure quality degradation and loss are bulk density (test weight), germination, dockage, foreign material, heat and insectdamaged kernel, visible and invisible mould, and fatty acid value. In some countries such as Canada, bulk density is measured using standardized equipment and procedures, and this tested bulk density is termed as test weight and reported in $\mathrm{kg} / \mathrm{hL}$. In the USA, a similar equipment and procedure are recommended and reported in $\mathrm{lb} / \mathrm{bu}$. Germination is mostly measured during a scientific study because it is a reliable method to evaluate grain quality (Jian et al. 2019b). It is usually assumed that DML increases with the decrease of germination and bulk density (test weight).

Quality degradation is originally quantified in terms of DML based on the work of Steel et al. (1969). The DML for different crops such as shelled corn (Brooker et al. 1992) and paddy (Gao et al. 1998; Sukabdi 1979) have been studied. Dry mass loss of paddy during storage increases with increasing temperature in the range of $10^{\circ} \mathrm{C}$ to $30^{\circ} \mathrm{C}$ (Sukabdi 1979). There is little if any, literature examining the DML of canola under different storage conditions. The relationship between DML and stored grain deterioration is used in many computerized simulations, development of recommendations for safe grain storage, and evaluation of storage loss. Storage time tables and graphs for shelled corn are based on an allowable DML (Brooker et al., 1992), and the recommendation in the ASABE standard is $0.5 \%$ (ASABE 2019). Mathematical models to calculate the storage time of shelled corn are also based on the $0.5 \%$ DML (Bern et al. 2002). However, the relationship between DML, test weight, and stored canola germination is unknown.

Dry mass loss of stored grains can be determined directly by measuring the mass at the start of the tests and periodically after that (Christensen and Meronuck 1989). After subtracting the mass contributed by the moisture content change, this measured mass can be converted to dry mass change, hence the DML. The disadvantage of this test is that the total amount of grain should be large enough (> $5 \mathrm{~kg}$ ) if a reliable accuracy of the measured DML is desired. Dry mass loss is usually less than $0.5 \%(25 \mathrm{~g}$ in $5 \mathrm{~kg})$. The error of the scale used for measuring $5 \mathrm{~kg}$ is generally higher than $0.1 \%$ ( $5 \mathrm{~g}$ in $5 \mathrm{~kg}$ sample). The grain sample might also change moisture content after the DML increases. If the oven method is used, the measurement error of the moisture content is $0.1 \%$ ( $5 \mathrm{~g}$ in $5 \mathrm{~kg}$ sample). Therefore, the total measurement error of this method is more than $40 \%$ of the DML if the sample unit is less than $5 \mathrm{~kg}$ because $[(5+5) / 25]$ $\times 100=40 \%$. Researchers used a sample of a few hundred grams to determine the DML (Christensen and Meronuck 1989). If the sample is too small, this measured DML might be questionable. It is not known whether this method is sensitive enough to determine DML when it is much smaller than $0.5 \%$.

There are indirect methods to determine DML, such as measuring total $\mathrm{CO}_{2}$ production (Seitz et al. 1982) and dry mass change of a thousand kernel mass. Measurement of the thousand kernel mass might be less reliable because it is difficult to determine whether one thousand kernels is the representative sample, and the same issue of the small sample as mentioned above. The amount of $\mathrm{CO}_{2}$ production has long been used as an indicator of respiration and DML of stored grain because substrates used throughout respiration are dry matter (Steele et al. 1969). Different substrates such as carbohydrates, fats, and proteins produce different amounts of $\mathrm{CO}_{2}$. Dry mass loss is estimated by assuming production of $14.66 \mathrm{~g} \mathrm{CO}_{2}$ per $\mathrm{kg}$ of original dry matter corresponds to a $1 \%$ loss of dry matter (Steele et al. 1969). It is not known whether the two methods (measuring $\mathrm{CO}_{2}$ production and mass change) can determine the same DML value for the same sample.

Measuring DML during commercial grain storage is challenging because of the time limitation during transportation and handling and sampling difficulty that arises from accessing large amounts of grain within a bin. In the grain industry, test weight measurement is a common practice. Germination is measured in any safe storage guideline study (Sun et al. 2014). These three parameters indicate grain quality. Establishing the relationships among the test weight, germination, and DML will be useful to the grain industry. It is not known whether the measured test weight and germination can be used to determine the DML. To the best of our knowledge, there is no study to find the relationship between the bulk density, germination, and DML of canola seeds.

The main objectives of this laboratory study were to 1) measure the DML of canola with 10, 12.5, and $15 \%$ moisture content at 25,30 , and $35^{\circ} \mathrm{C}$ by using $10 \mathrm{~kg}$ of sample; 2) evaluate the relationship among the DML, germination, and test weight; 3) compare DML values estimated by the produced $\mathrm{CO}_{2}$ and measuring mass change; and 4) determine the deterioration difference between sound and mouldy canola. 


\section{MATERIALS AND METHODS}

\section{Canola preparation}

Two sources (fresh and stored) of canola (Polish Bayer L233P) were purchased from the same farmer located south of Winnipeg. The fresh canola (about $500 \mathrm{~kg}$ ) was directly transferred to the lab at the harvest time, and its moisture content was measured by using ASABE standard (ASABE $2016 \mathrm{a}$ ) at $130^{\circ} \mathrm{C}$ and $4 \mathrm{~h}$ (all the moisture content mentioned in this study was measured by using this method). The moisture content was $7.3 \pm 0.1 \%$ (wet basis) and was adjusted to $10.0 \pm 0.1 \%$ by adding distilled water and mixing for 30 min (Jian et al. 2019b). Percentages of chaff, broken kernels, and germination were $1.7 \pm 0.3 \%, 0.8 \pm 0.5$ $\%, 91 \pm 2 \%$, respectively. The conditioned canola was stored at $5 \pm 1{ }^{\circ} \mathrm{C}$ for about 2 weeks inside double-layer plastic bags before use (referred to as Sound canola). About three-quarters of the Sound canola was directly used to conduct the DML test. Another source of canola (stored and aerated canola) was harvested the previous year of the Sound canola and stored for 6 mon in a farm bin which was aerated until canola temperature was 5 to $10^{\circ} \mathrm{C}$ at the beginning of the storage (aeration was stopped at the end of October). After storage, the moisture content was $6.7 \pm$ $0.4 \%$, and there was no significant difference in chaff, broken kernels, and germination between the two sources of canola.

After the stored and aerated canola was delivered to the lab, the moisture content was adjusted to $10.0 \pm 0.1 \%$ by adding distilled water and mixing for $30 \mathrm{~min}$. This conditioned canola was sealed in double-layer plastic bags and then stored at room temperature $\left(25 \pm 3^{\circ} \mathrm{C}\right.$ and 30 to $45 \% \mathrm{RH}$ ) for about 6 months. At the end of storage, the canola stored at room temperature spoiled, and the germination was lower than 30\% (Sun et al. 2014). The infected mould species were identified using the method reported by White et al. (1982a), and the following species were found: Penicillium spp., Aspergillus glaucus group, Aspergillus candidus Link, and Alternaria alternata (Fr.) Keissler (Sun et al. 2014). One-quarter of the Sound canola was mixed with three-quarters of the spoiled canola. Germination of canola was measured using the method reported by Sun et a. (2014), and this mixed canola (referred to as Mouldy canola) had germination of $43.3 \pm 2.3 \%$. The reason for choosing this mixing ratio was to measure DML under the worst scenario of grain mixing or loading newly harvested canola into an uncleaned bin with a certain amount of spoiled canola. These prepared Mouldy canola seeds were kept at $5 \pm 1{ }^{\circ} \mathrm{C}$ inside double-layer plastic bags for about 2 weeks before use.

After this 2-week storage at $5 \pm 1{ }^{\circ} \mathrm{C}$, the moisture content of Mouldy and Sound canola was individually adjusted to $10,12.5$, and $15 \%$ by adding desired amounts of distilled water and mixing for $30 \mathrm{~min}$ (Sun et al. 2014). Under these moisture contents at 25 to $30^{\circ} \mathrm{C}$, the relative humidity inside the canola bags was higher than $75 \%$ (ASABE 2016b), resulting in canola spoilage so that the DML could be measured. The conditioned canola was stored in double-layer plastic bags inside an environmental chamber (Conviron CMP3244, Controlled Environments Ltd., Winnipeg, MB, Canada) for 2 weeks before use. The chamber was set at $5 \pm 1^{\circ} \mathrm{C}$ and $75 \pm 5 \% \mathrm{RH}$.

\section{Test procedure}

The prepared Sound and Mouldy canola at three moisture contents $(10,12.5$, and $15 \%)$ were loaded into double-layer plastic bags individually, and each bag was $10 \mathrm{~kg}$. The bagged canola was stored inside environmental chambers (Conviron CMP3244, Controlled Environments Ltd., Winnipeg, MB, Canada) at 25, 30, $35 \pm 1^{\circ} \mathrm{C}$ and $75 \pm 5 \%$ RH. There was a total of nine experiments for the Sound canola (three moisture contents and three temperatures, Table 1), and each experiment represents a storage condition (a combination of temperature and moisture content). The same number of experiments were conducted for the Mouldy canola (Table 1). There were three replicates for each experiment. The measurement order of the experiments was randomly selected at the first measurement time, and the same order was used after that, so the storage time among the experiments at each measurement was the same.

The total mass, test weight, moisture content, and germination inside each bag and at each storage condition were measured before the canola was stored in the environmental chambers and reported as the initial condition. The total mass $(\mathrm{kg})$ of each bag was measured using a scale with a precision of $0.01 \mathrm{~g}$. Before using, the scale was calibrated by using the same metal weight. The

Table 1. Moisture content of the tested canola.

\begin{tabular}{|c|c|c|c|c|c|}
\hline \multirow[t]{2}{*}{$\mathrm{T}^{\mathrm{a}}$} & \multirow{2}{*}{$\begin{array}{c}\text { Nominal } \\
\mathrm{MC}^{\mathrm{b}}\end{array}$} & \multicolumn{2}{|c|}{ Sound canola } & \multicolumn{2}{|c|}{ Mouldy canola } \\
\hline & & Initial $\mathrm{MC}^{\mathrm{b}}$ & Final $\mathrm{MC}^{\mathrm{b}}$ & Initial $\mathrm{MC}^{\mathrm{b}}$ & Final $\mathrm{MC}^{\mathrm{b}}$ \\
\hline \multirow{3}{*}{25} & 10 & $10.1 \pm 0.0$ & $9.5 \pm 0.1$ & $10.4 \pm 0.1$ & $10.2 \pm 0.0$ \\
\hline & 12.5 & $12.7 \pm 0.0$ & $12.1 \pm 0.1$ & $12.6 \pm 0.1$ & $12.3 \pm 0.0$ \\
\hline & 15 & $15.1 \pm 0.0$ & $14.8 \pm 0.1$ & $15.0 \pm 0.0$ & $15.1 \pm 0.0$ \\
\hline \multirow{3}{*}{30} & 10 & $10.1 \pm 0.0$ & $10.0 \pm 0.0$ & $10.3 \pm 0.0$ & $10.3 \pm 0.0$ \\
\hline & 12.5 & $12.7 \pm 0.0$ & $12.6 \pm 0.0$ & $12.5 \pm 0.0$ & $12.3 \pm 0.0$ \\
\hline & 15 & $15.0 \pm 0.0$ & $15.1 \pm 0.1$ & $15.0 \pm 0.0$ & $15.3 \pm 0.0$ \\
\hline \multirow{3}{*}{35} & 10 & $10.1 \pm 0.0$ & $9.8 \pm 0.0$ & $10.2 \pm 0.0$ & $10.2 \pm 0.0$ \\
\hline & 12.5 & $12.7 \pm 0.0$ & $12.3 \pm 0.0$ & $12.4 \pm 0.1$ & $12.4 \pm 0.0$ \\
\hline & 15 & $15.1 \pm 0.1$ & $15.4 \pm 0.1$ & $14.9 \pm 0.1$ & $15.3 \pm 0.1$ \\
\hline
\end{tabular}

${ }^{a}$ Temperature $\left({ }^{\circ} \mathrm{C}\right) .{ }^{b} \mathrm{MC}=$ moisture content $(\%$, wet basis $)$. 
method recommended by the Canadian Grain Commission (2019) was used to measure test weight. The unit of the test weight was reported in $\mathrm{kg} / \mathrm{m}^{3}$ due to the SI unit requirement and to avoid confusion with the test weight measured by the USDA method. All canola in a bag was used to measure test weight, and the time for each measurement was less than 5 min. The moisture content was determined by drying triple samples weighing about $10 \mathrm{~g}$ at $130^{\circ} \mathrm{C}$ for $4 \mathrm{~h}$. Twenty-five kernels were selected from each bag to measure germination by following the procedure reported by Jian et al. (2019a). The selected kernels were placed in a $90 \mathrm{~mm}$ diameter petri dish with a filter paper (No. 3 Whatman) soaked with $5 \mathrm{~mL}$ of distilled water and incubated at room temperature $\left(25 \pm 2^{\circ} \mathrm{C}\right)$. The number of sprouted kernels was counted $7 \mathrm{~d}$ later. Each bag was opened for 5 min every week to produce a non-airtight condition (White et al. 1982a). Every 2 week, the total mass, moisture content, test weight, and germination of the canola inside each bag and at each storage condition were measured (the measurement order was the same as stated). The experiment ended at 14 weeks for the Sound canola and 4 week for the Mouldy canola, or when the germination was less than $10 \%$. At the end of the experiment, species of the infected fungi were identified by placing 25 randomly selected seeds on a filter paper (No. 3 Whatman) in a Petri dish (Mills and Sinha 1980, White et al. 1982a, Sun et al. 2014). The filter paper was saturated with $5.0 \mathrm{~mL}$ of $7.5 \%$ aqueous sodium chloride solution. After $7 \mathrm{~d}$ of incubation at room temperature $(25 \pm$ $2^{\circ} \mathrm{C}$ ), the number of seeds infected by fungi was counted, and species of the fungi were identified under a microscope. The result of fungi infection was not reported in this article because 1) there was no difference between different treatments due to heavy infection at the end of the experiment; 2) the result was the same as that reported by Sun et al. (2014) at the storage condition of 20 and $30^{\circ} \mathrm{C}$ and 10 to $14 \%$ moisture contents; and 3) the conclusion and result were reported in the literature (White et al. 1982a, Pronyk et al. 2006, Jian et al. 2014b).

\section{Data analysis}

Percentage of test weight change, DML, and germination decrease rate The percentage of test weight change $(P T W, \%)$ was calculated as:

$$
\text { PTW }(\%)=\frac{W_{0}-W_{n}}{W_{0}} 100
$$

where, $W_{o}=$ initial test weight in the bag $\left(\mathrm{kg} / \mathrm{m}^{3}\right), W_{n}=$ test weight of the canola at $n$ week in the bag $\left(\mathrm{kg} / \mathrm{m}^{3}\right)$.

To calculate the DML, the dry mass of canola in each bag was calculated as:

$$
M_{d}=M_{w}(1-M C)
$$

where, $M_{d}=$ dry mass in the bag $(\mathrm{kg}) ; M_{w}=$ total mass in the bag, $M C=$ moisture content in the bag (wet basis, decimal).

Dry mass loss (referred to as Measured-DML, \%) was calculated as:

$$
\operatorname{DML}(\%)=\frac{M_{d 0}-M_{d n}}{M_{d o}} \times 100
$$

where, $M_{d 0}=$ initial dry mass of the canola in the bag $(\mathrm{kg})$, $M_{d n}=$ dry mass of the canola at $n$ week of storage in the bag $(\mathrm{kg})$.

To evaluate deterioration rate, germination decrease rate (GDR, \%/week) was calculated as:

$$
G D R=\frac{G_{0}-G_{n}}{G_{0} n} \times 100 \%
$$

where, $G_{o}=$ initial germination (\%), and $G_{n}=$ germination of the canola at $n$ week of storage. In this study, $n=2$ week.

To check whether the Mouldy canola had a faster decrease in test weight, Student's t-test was conducted to compare the difference in PTW between the Mouldy and Sound canola stored under the same conditions over a 2-week period. The same comparison was conducted for the Measured-DML and GDR.

Relationship between Measured-DML and germination or bulk density To find the main factor influencing the DML, a two-way ANOVA was applied to test the DML of the Sound canola in 4 and 6 week of storage times (SigmaPlot, V13.2, Systat Software, Inc., San Jose, California). The factors are temperature and moisture content. The reason for selecting 4 and 6 week was that complete data were available only for these storage times, and there were 0 DML in 2 weeks. The same test was conducted for the Mouldy canola in 2 week of storage time. Tukey test was used to conduct the two-way test. To find the relationship between DML and germination, the data associated with the Sound canola was further analyzed by performing Spearman Rank Order correlation and linear regression. The same test was conducted for the test weight. Nonlinear regression was performed to find whether temperature and moisture content influence this relationship. The same test was conducted for the moisture content. It was assumed there were interactions among DML, germination, test weight, temperature, and moisture content. Therefore, the product of two and three of the factors was added to the linear equation. The values of coefficient of determination $\left(\mathrm{R}^{2}\right)$ and residual mean square error (MS) were used to evaluate whether the added products could influence the predicted DML under the storage conditions. The increase of $\mathrm{R}^{2}$ and decrease of residual of MS indicated the influence of the added product(s) on the DML.

Difference between measured and estimated DML The $\mathrm{CO}_{2}$ production of canola with 14,12 , and $10 \%$ moisture content at $30^{\circ} \mathrm{C}$ in $3 \mathrm{~d}$ airtight time reported by Jian et al. (2014b) was used to estimate the DML of canola by using the assumption that $14.66 \mathrm{~g} \mathrm{CO}_{2}$ per $\mathrm{kg}$ of dry matter corresponds to a 1\% loss of dry matter (Steele et al. 1969, Seitz et al. 1982). This estimated DML was referred to as Estimated-DML. Paired t-tests were conducted to compare the mean values of Estimated- and Measured-DML at the similar storage conditions over 4 and 8 weeks of storage, e.g., Estimated-DML associated with 14, 12, and 10\% MC 

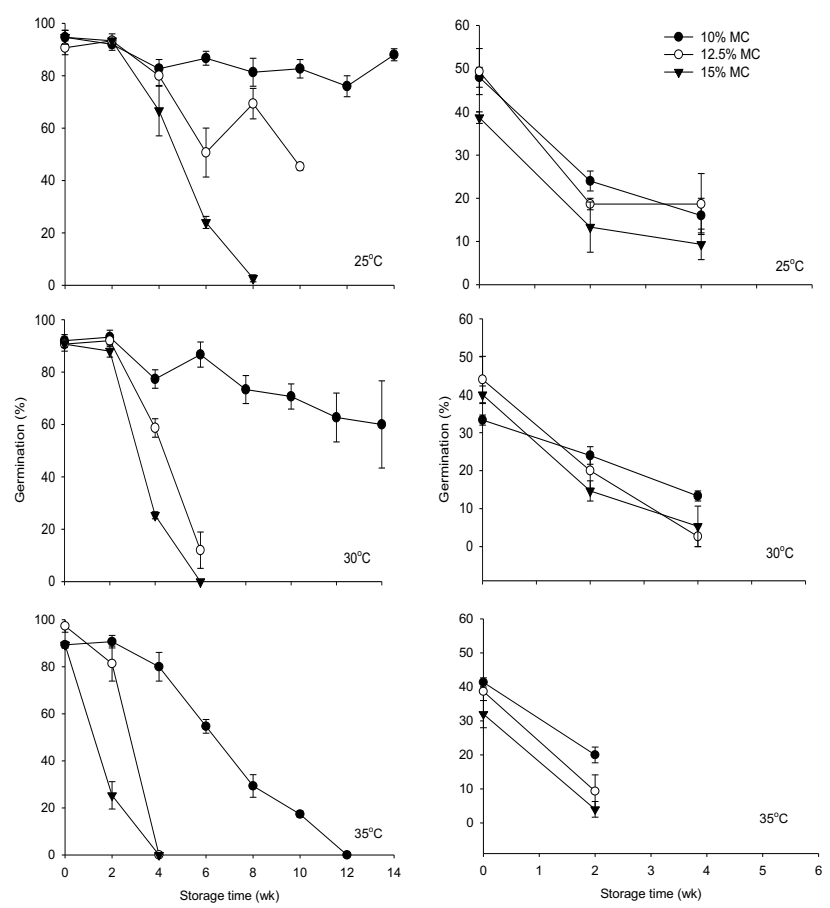

Fig. 1. Germination (\%) of the Sound (left) and Mouldy (right) canola stored at different temperatures and moisture contents. MC is the nominal moisture content (\%, wet basis) in the legend. Error bar is the standard error.

of canola at $30^{\circ} \mathrm{C}$ was compared with the Measured-DML associated with $15,12.5$, and $10 \% \mathrm{MC}$ of canola at $30^{\circ} \mathrm{C}$, respectively. The reason for the comparison between $14 \%$ and $15 \%$ MC was that: 1) Jian et al. (2014b) did not report $\mathrm{CO}_{2}$ production of $15 \% \mathrm{MC}$ canola; 2 ) the closest moisture content reported by Jian et al. (2014b) was $14 \%$, and 3) we would like to find whether the two high moisture contents would result in the similar DML. There was no significant difference between the $12.5 \%$ nominal MC reported by Jian et al. (2014b) and the $12 \%$ nominal MC in this study due to moisture loss or gain during testing.

\section{RESULTS}

\section{Moisture content}

The initial moisture content of Sound and Mouldy canola seeds had less than 0.6 percentage point difference from the nominal moisture contents (Table 1). At the end of the experiments, canola lost or gained less than 0.6 percentage points of its initial MC at any nominal MC. Therefore, the tested canola was nearly controlled at constant moisture contents. Moisture loss occurred due to evaporation when the bags were opened for air exchange and measured the test weight. In contrast, an increase in moisture could be explained by the respiration of spoiled canola and/or fungi.
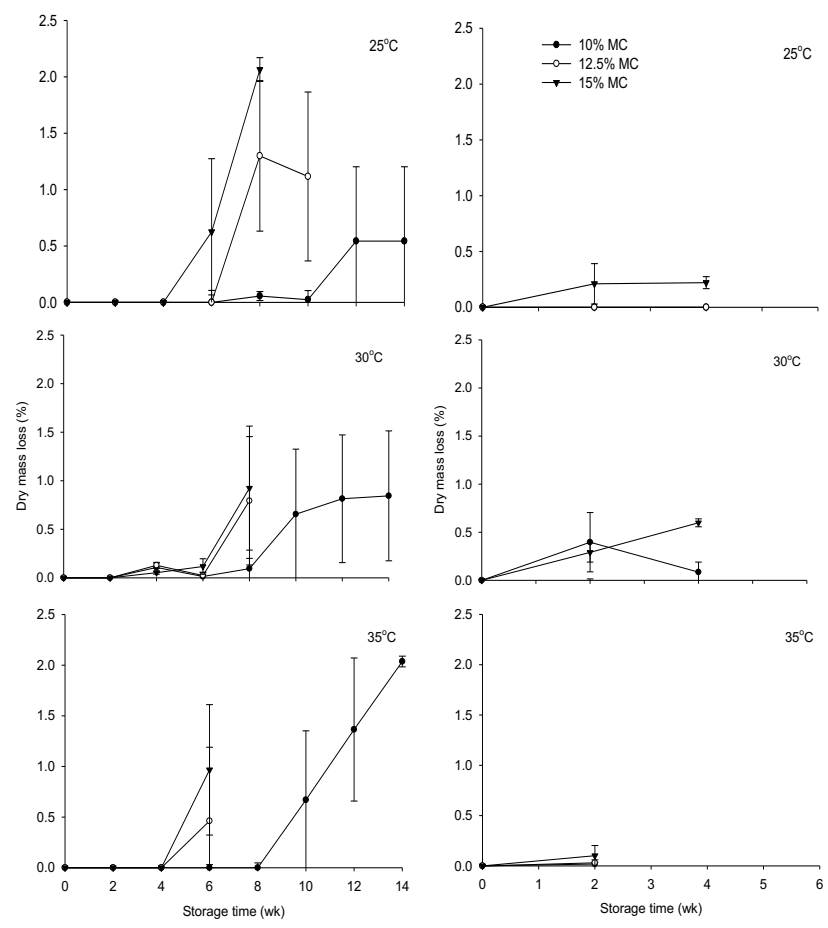

Fig. 2. Dry mass loss (\%) of the Sound (left) and Mouldy (right) canola stored at different temperatures and moisture contents. MC is the nominal moisture content $(\%$, wet basis) in the legend. Error bar is the standard error.

This lost or gained water was considered in the DML calculation (Eq. 2).

\section{Germination, DML, and test weight}

The dry mass loss increased with a decrease of germination (Figs. 1 and 2) and test weight (Fig. 3). For this reason, the Spearmen Rank Order correlation was conducted. The coefficient of the Spearmen Rank Order correlation between DML and germination or between DML and PTW was greater than 0.52 for temperatures higher than $30^{\circ} \mathrm{C}$ or higher than 0.46 for moisture contents over $12.5 \%$ (Table 2). There was a significant relationship between the DML and germination or between DML and PTW in 18 of 24 cases (Table 2). The Spearman Rank Order correlation coefficient at $25^{\circ} \mathrm{C}$ and/or $10 \% \mathrm{MC}$ was usually lower than values at higher temperatures and/or higher moisture contents. This result indicated a stronger correlation between germination and test weight at higher moisture contents and temperatures.

\section{Difference between Mouldy and Sound canola}

The germination decrease rate (GDR) of $12.5 \% \mathrm{MC}$ Mouldy canola over 2 week at 25,30 , and $35^{\circ} \mathrm{C}$ was found to be $30.8 \pm 1.8,24.8 \pm 8.5$, and $37.0 \pm 6.7 \%$ /week as 

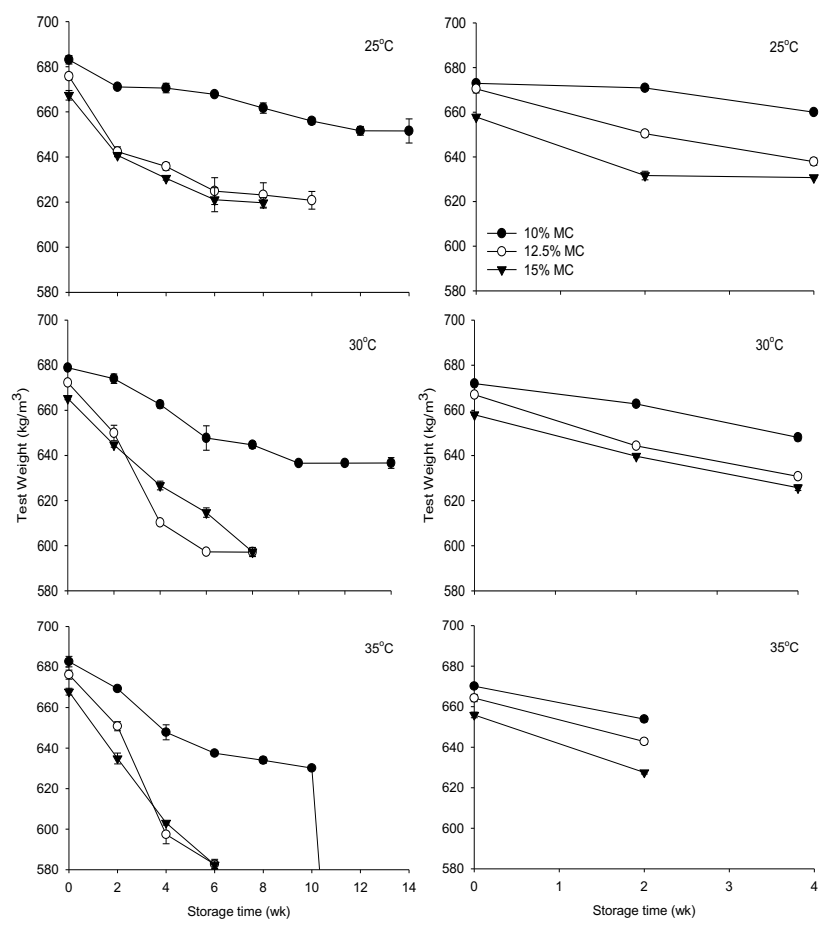

Fig. 3. Test weight $\left(\mathrm{kg} / \mathrm{m}^{3}\right)$ of the Sound (left) and Mouldy (right) canola at different storage conditions. MC is the nominal moisture content (\%, wet basis) in the legend. Error bar is the standard error.

compared to $0.0 \pm 0.0,0.0 \pm 0.0$, and $8.3 \pm 3.2 \% /$ week for Sound canola, respectively (Fig. 1 and Table 3 ). Therefore, the GDR was significantly higher for the Mouldy canola than the Sound canola except at $15 \% \mathrm{MC}$ and $35^{\circ} \mathrm{C}$ (Fig. 1, Table 3). The quick spoilage of Sound canola caused the exception under this condition. This indicated that the Mouldy canola lost germination faster than the Sound

Table 3. Germination decrease rate (GDR) of Mouldy and Sound canola in 2 week-storage time.

\begin{tabular}{|c|c|c|c|c|c|}
\hline \multirow[t]{2}{*}{$\mathrm{T}^{\mathrm{a}}$} & \multirow{2}{*}{$\begin{array}{l}\mathrm{MC} \\
(\%)\end{array}$} & \multicolumn{2}{|c|}{ GDR (\%/week) } & \multicolumn{2}{|c|}{ Comparison } \\
\hline & & Sound & Mouldy & $t^{b}$ & $P^{c}$ \\
\hline \multirow{3}{*}{25} & 10 & $2.0 \pm 2.0$ & $24.8 \pm 3.4$ & 5.780 & $0.004^{* *}$ \\
\hline & 12.5 & $0.0 \pm 0.0$ & $30.8 \pm 1.8$ & $\begin{array}{r}17.11 \\
1\end{array}$ & $<0.001^{* * *}$ \\
\hline & 15 & $0.0 \pm 0.0$ & $32.2 \pm 8.3$ & 3.880 & $0.018^{*}$ \\
\hline \multirow{4}{*}{30} & 10 & $0.7 \pm 0.7$ & $13.9 \pm 3.9$ & 3.331 & $0.029^{*}$ \\
\hline & 12.5 & $0.0 \pm 0.0$ & $24.8 \pm 8.5$ & 2.918 & $0.043^{*}$ \\
\hline & 15 & $1.5 \pm 1.5$ & $31.2 \pm 4.5$ & 6.261 & $0.003^{* *}$ \\
\hline & 10 & $0.7 \pm 0.7$ & $25.8 \pm 3.0$ & 8.148 & $0.001^{* *}$ \\
\hline \multirow[t]{2}{*}{35} & 12.5 & $8.3 \pm 3.2$ & $37.0 \pm 6.7$ & 3.865 & $0.018^{*}$ \\
\hline & 15 & $35.8 \pm 3.3$ & $42.6 \pm 4.9$ & 1.151 & 0.314 \\
\hline
\end{tabular}

${ }^{\mathrm{a}}$ Temperature $\left({ }^{\circ} \mathrm{C}\right)$

${ }^{\mathrm{b}} \mathrm{c} T h e t$ value and probability of the Student t-test, respectively $(\mathrm{DF}=4)$. Significant at $\alpha \leq 0.05^{*}, \leq 0.01^{* *}, \leq 0.001^{* * *}$.
Table 2. Spearman Rank Order correlation between dry mass loss (DML) and germination or percentage of test weight change (PTW).

\begin{tabular}{cllccccc}
\hline $\mathrm{T}^{\mathrm{a}}$ & MC (\%) & \multicolumn{2}{c}{$\begin{array}{c}\text { DML and } \\
\text { Germination }\end{array}$} & & \multicolumn{2}{c}{ DML and PTW } \\
\cline { 3 - 4 } \cline { 6 - 7 } & & \multicolumn{2}{c}{$r^{b}$} & $P^{c}$ & & $r^{b}$ & $P^{c}$ \\
\hline \multirow{2}{*}{25} & 10 & 12.5 & -0.28 & 0.283 & & 0.48 & 0.06 \\
& 15 & -0.84 & $0.013^{*}$ & & 0.46 & 0.10 \\
& 10 & -0.58 & $0.001^{* * *}$ & & 0.76 & $<0.001^{* * *}$ \\
30 & 12.5 & -0.87 & $<0.001^{* * *}$ & & 0.43 & 0.09 \\
& 15 & -0.80 & $<0.001^{* * *}$ & & 0.82 & $<0.001^{* * *}$ \\
& 10 & -0.75 & $<0.001^{* * *}$ & & 0.78 & $<0.001^{* * *}$ \\
35 & 12.5 & -0.78 & $<0.001^{* * *}$ & & 0.52 & 0.07 \\
& 15 & -0.82 & $<0.001^{* * *}$ & & 0.53 & 0.08 \\
25 & $10-15^{\text {d }}$ & -0.64 & $<0.001^{* * *}$ & & 0.55 & $<0.001^{* * *}$ \\
30 & $10-15^{\mathrm{d}}$ & -0.76 & $<0.001^{* * *}$ & & 0.66 & $<0.001^{* * *}$ \\
35 & $10-15^{\mathrm{d}}$ & -0.74 & $<0.001^{* * *}$ & & 0.65 & $<0.001^{* * *}$ \\
\hline
\end{tabular}

aTemperature $\left({ }^{\circ} \mathrm{C}\right)$.

${ }^{\mathrm{b}}$ Coefficient of the Spearman Rank Order correlation, and ${ }^{\mathrm{c}} P$-value of the Spearman Rank Order correlation. The DF of the correlation was 2 .

${ }^{\mathrm{d}}$ All the data at the same temperature were pooled.

Significant at $\alpha \leq 0.05^{*}, \leq 0.01^{* *}, \leq 0.001^{* * *}$.

canola at the beginning of the storage under any storage condition (Fig. 1). The percentages of test weight change (PTW) of the $12.5 \% \mathrm{MC}$ Mouldy canola at 25,30 , and $35^{\circ} \mathrm{C}$ over 2 weeks were $2.5 \pm 0.2,2.7 \pm 0.2$, and $3.2 \pm 0.2 \%$ respectively; while at the same storage condition, the PTW of the Sound canola was $4.9 \pm 0.3,3.5 \pm 0.2,3.8 \pm 0.2 \%$, respectively (Fig. 3). No significant difference of PTW between Mouldy and Sound canola was found at $35^{\circ} \mathrm{C}$ (student t-test, Table 4). These results indicated the same decrease rate of the bulk density between the Mouldy and Sound canola at $35^{\circ} \mathrm{C}$. A significant difference of DML between Mouldy and Sound canola was recorded at $15 \%$

Table 4. Student t-test of dry mass loss (DML) and percentage of test weight change (PTW) between Mouldy and Sound canola in 2 weekstorage time.

\begin{tabular}{|c|c|c|c|c|c|}
\hline \multirow[t]{2}{*}{$\mathrm{T}^{\mathrm{a}}$} & \multirow{2}{*}{$\begin{array}{l}\mathrm{MC} \\
(\%)\end{array}$} & \multicolumn{2}{|c|}{ DML (\%) } & \multicolumn{2}{|c|}{ PTW (\%) } \\
\hline & & $t^{b}$ & $\mathrm{P}^{\mathrm{c}}$ & $\mathrm{t}^{\mathrm{b}}$ & $\mathrm{P}^{\mathrm{c}}$ \\
\hline \multirow{3}{*}{25} & 10 & 0.00 & 1.0 & 0.155 & 0.884 \\
\hline & 12.5 & 0.00 & 1.0 & 7.197 & $0.002^{*}$ \\
\hline & 15 & 4.11 & $0.015^{*}$ & 3.341 & $0.029^{*}$ \\
\hline \multirow{3}{*}{30} & 10 & 0.19 & 0.895 & 4.494 & $0.011^{*}$ \\
\hline & 12.5 & 1.58 & 0.190 & 15.399 & $<0.001^{* * *}$ \\
\hline & 15 & 12.39 & $<0.001^{* * *}$ & 0.833 & 0.452 \\
\hline \multirow{3}{*}{35} & 10 & 1.00 & 0.374 & 1.302 & 0.263 \\
\hline & 12.5 & 1.00 & 0.374 & 0.759 & 0.499 \\
\hline & 15 & 9.02 & $<0.001^{* * *}$ & 1.322 & 0.257 \\
\hline
\end{tabular}

${ }^{\mathrm{a}}$ Temperature $\left({ }^{\circ} \mathrm{C}\right) .{ }^{\mathrm{b}} \mathrm{The} \mathrm{t}$ value and probability of the Student $t$ test, respectively $(\mathrm{DF}=4)$. Significant at $\alpha \leq 0.05^{*}, \leq 0.01^{* *}, \leq$ $0.001^{* * *}$. 


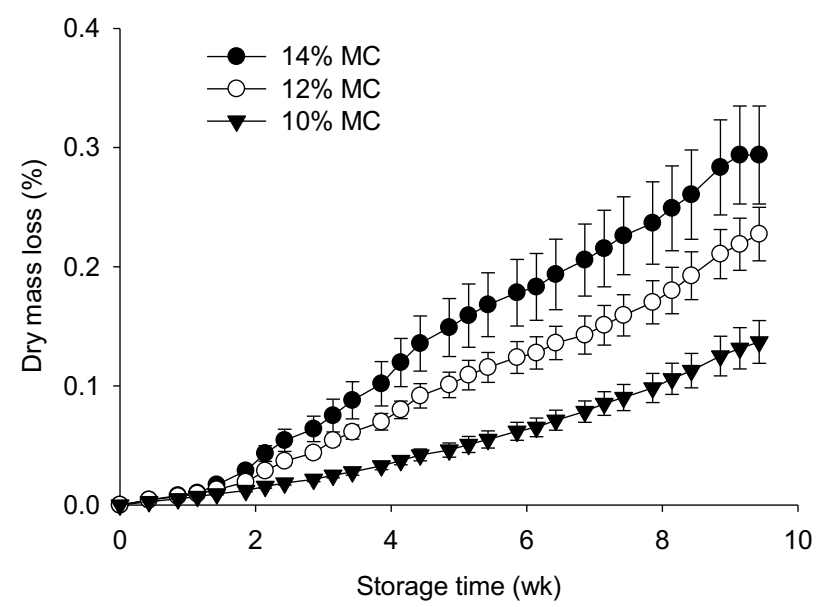

Fig. 4. Estimated dry mass loss of canola with 14,12 , and $10 \%$ moisture contents at $30^{\circ} \mathrm{C}$. The estimated dry mass loss was based on the measured $\mathrm{CO}_{2}$ concentration reported by Jian et al. (2014b). MC is the nominal moisture content ( $\%$, wet basis) in the legend. Error bar is the standard error.

MC for all temperatures (Table 4). This indicated that at the same storage condition and in the same storage period, the mouldy canola had a greater DML and GDR than the sound canola (Figs. 1 and 2, Table 3). This result was expected because mouldy canola would continue to spoil due to initial heavy mould infestation, which resulted in heavy spoilage of the canola, hence a higher dry mass loss and germination loss. Therefore, mixing spoiled canola with
Table 5. Results of two-way ANOVA of dry mass loss (DML) of Sound and Mouldy canola.

\begin{tabular}{llllll}
\hline Canola & Time $^{\mathrm{a}}$ & $\mathrm{St}^{\mathrm{b}}$ & $\mathrm{T}^{\mathrm{c}}$ & $\mathrm{MC}^{\mathrm{d}}$ & $\mathrm{T} \times \mathrm{MC}^{\mathrm{e}}$ \\
\hline Sound & 4 & $\mathrm{~F}$ & 1.515 & 0.837 & 0.967 \\
& & $\mathrm{P}$ & 0.247 & 0.449 & 0.449 \\
& 6 & $\mathrm{~F}$ & 0.210 & 4.604 & 0.741 \\
& & $\mathrm{P}$ & 0.812 & $0.024^{*}$ & 0.577 \\
Mouldy & 2 & $\mathrm{~F}$ & 59.043 & 393.195 & 94.049 \\
& & $\mathrm{P}$ & $<0.001^{* * *}$ & $<0.0001^{* * *}$ & $<0.0001^{* * *}$ \\
\hline
\end{tabular}

Storage time (week). ${ }^{\mathrm{b}} \mathrm{F}$ and $\mathrm{P}$ value of the two-way ANOVA (DF $=26$ ). ${ }^{\mathrm{c}}$ Temperature $\left({ }^{\circ} \mathrm{C}\right)$. ${ }^{\mathrm{d}}$ Moisture content (wet basis, \%). ${ }^{\mathrm{e}}$ Interaction between temperature and moisture content. Significant at $\alpha \leq 0.05^{*}, \leq 0.01^{* *}, \leq 0.001^{* * *}$.

sound canola resulted in faster spoilage, more DML, higher PTW, and lower germination under any storage condition.

Relationship between DML and germination or PTW

Two-way ANOVA tests showed that the moisture content was the significant factor causing the DML of the Sound canola. In contrast, both temperature and moisture content and their interaction were the significant factors causing the DML of the Mouldy canola (Table 5). Results of regressions among Measured-DML and germination, temperature, and/or moisture content are presented in table 6 . The coefficient of determination $\left(\mathrm{R}^{2}\right)$ for all regression equations was lower than 0.66 (Table 6). More than 30 linear and nonlinear equations were regressed in this study to fit the data of Measured-DML and germination. The equations presented in tables 6 provided the highest $\mathrm{R}^{2}$ values of those tested. We had the same conclusion for the PTW. Therefore, the regression equations with the

Table 6. Results of regression among Measured-DML and germination, temperature, and / or moisture content.

\begin{tabular}{|c|c|c|c|c|}
\hline \multicolumn{2}{|c|}{ Storage condition } & Regression equation $^{\mathrm{a}}$ & $\mathrm{R}^{2}$ & $\mathrm{RMS}^{\mathrm{b}}$ \\
\hline \multirow[t]{5}{*}{$25^{\circ} \mathrm{C}$} & $10 \% \mathrm{MC}$ & $=0.143-0.0015 \mathrm{G}$ & 0.09 & 0.002 \\
\hline & $12.5 \% \mathrm{MC}$ & $=1.956-0.0218 \mathrm{G}$ & 0.43 & 0.290 \\
\hline & $15 \% \mathrm{MC}$ & $=1.652-0.0194 \mathrm{G}$ & 0.66 & 0.315 \\
\hline & 10 to $15 \%$ & $=1.721-0.0192 \mathrm{G}$ & 0.50 & 0.226 \\
\hline & $\mathrm{MC}$ & $=1.3993+0.0191 \mathrm{MC}-0.0151 \mathrm{G}-0.0003 \mathrm{MCG}$ & 0.61 & 0.210 \\
\hline \multirow[t]{5}{*}{$30^{\circ} \mathrm{C}$} & $10 \% \mathrm{MC}$ & $=1.466-0.0160 \mathrm{G}$ & 0.20 & 0.240 \\
\hline & $12.5 \% \mathrm{MC}$ & $=0.681-0.0075 \mathrm{G}$ & 0.18 & 0.327 \\
\hline & $15 \% \mathrm{MC}$ & $=0.669-0.00776 \mathrm{G}$ & 0.27 & 0.308 \\
\hline & 10 to $15 \%$ & $=0.858-0.00914 \mathrm{G}$ & 0.22 & 0.325 \\
\hline & & $=1.8696-0.0829 \mathrm{MC}-0.0184 \mathrm{G}+0.0007 \mathrm{MCG}$ & 0.21 & 0.365 \\
\hline \multirow[t]{5}{*}{$35^{\circ} \mathrm{C}$} & $10 \% \mathrm{MC}$ & $=1.666-0.0209 \mathrm{G}$ & 0.60 & 0.374 \\
\hline & $12.5 \% \mathrm{MC}$ & $=1.754-0.0193 \mathrm{G}$ & 0.09 & 0.069 \\
\hline & $15 \% \mathrm{MC}$ & $=0.650-0.0086 \mathrm{G}$ & 0.22 & 0.487 \\
\hline & 10 to $15 \% \mathrm{MC}$ & $=1.284-0.0155 \mathrm{G}$ & 0.47 & 0.399 \\
\hline & & $=3.7-0.1999 \mathrm{MC}-0.047 \mathrm{G}+0.0026 \mathrm{MCG}$ & 0.57 & 0.346 \\
\hline \multirow[t]{2}{*}{$10 \% \mathrm{MC}$} & 25 to $35^{\circ} \mathrm{C}$ & $=1.598-0.0185 \mathrm{G}$ & 0.57 & 0.217 \\
\hline & & $=-1.4516+0.0889 * \mathrm{~T}+0.0215 \mathrm{G}-0.0012 \mathrm{TG}$ & 0.58 & 0.220 \\
\hline \multirow[t]{2}{*}{$12.5 \% \mathrm{MC}$} & 25 to $35^{\circ} \mathrm{C}$ & $=1.195-0.0130 \mathrm{G}$ & 0.35 & 0.281 \\
\hline & & $=1.5239-0.0112 \mathrm{~T}-0.0137 \mathrm{G}+0.0208 * 10^{3} \mathrm{TG}$ & 0.35 & 0.298 \\
\hline \multirow[t]{4}{*}{$15 \% \mathrm{MC}$} & 25 to $35^{\circ} \mathrm{C}$ & $=0.991-0.0118 \mathrm{G}$ & 0.36 & 0.400 \\
\hline & & $=4.0068-0.1006 \mathrm{~T}-0.0451 \mathrm{G}+0.0011 \mathrm{TG}$ & 0.47 & 0.352 \\
\hline & & $=5.6472-0.1679 \mathrm{MC}-0.0715 \mathrm{~T}-0.0399 \mathrm{G}+0.0634^{*} 10^{3} \mathrm{MCTG}$ & 0.47 & 0.27 \\
\hline & & $\begin{aligned}= & 5.620-0.179 \mathrm{MC}-0.066 \mathrm{~T}-0.056 \mathrm{G}+0.016^{*} 10^{3} \mathrm{MCTG}+ \\
& 0.002 \mathrm{MCG}+0.0005 \mathrm{TG}\end{aligned}$ & 0.44 & 0.28 \\
\hline
\end{tabular}

a The regression equation for calculating DML, $\mathrm{G}=$ germination, $\mathrm{MC}=$ moisture content $(\%)$, and $\mathrm{T}=$ temperature $\left({ }^{\circ} \mathrm{C}\right),{ }^{\mathrm{b}} \mathrm{Residual}$ of the $\mathrm{MS}$, and $\mathrm{DF}=2$ for each temperature or moisture content, 8 at a temperature and pooled moisture or a moisture content and pooled temperature, and 26 for the last equation in the table. 
Table 7. Results of Paired t-test to compare between the Measured- and Estimated-DML under similar storage conditions.

\begin{tabular}{llll}
\hline $\begin{array}{c}\text { Storage time } \\
\text { (week) }\end{array}$ & Comparison $^{\mathrm{a}}$ & $t^{b}$ & $P^{c}$ \\
\hline 4 & $15 \%-14 \%$ & 1.464 & 0.281 \\
& $12.5 \%-12 \%$ & 0.301 & 0.792 \\
& $10 \%-10 \%$ & 0.019 & 0.986 \\
8 & $15 \%-14 \%$ & 2.427 & 0.072 \\
& $12.5 \%-12 \%$ & 0.896 & 0.421 \\
& $10 \%-10 \%$ & 1.078 & 0.342 \\
\hline
\end{tabular}

an the column, the percentage before the "-" is the MC of the canola used to measure the DML, while after the "-" is the MC of canola used to estimate the DML. ${ }^{\mathrm{b}}$ Value of $t$ and $P$ of the Paired $t$-test, respectively $(\mathrm{DF}=2)$.

germination or test weight as the independent parameter had a low prediction accuracy of the DML.

Generally speaking, the value of $\mathrm{R}^{2}$ at each tested condition was not higher than when more parameters were regressed (Table 6). This result was consistent with the twoway ANOVA test. Therefore, an equation including temperature and/or moisture content as independent parameters did not increase the prediction accuracy of the regression equations.

\section{Measured and calculated DML}

The comparisons between the measured- and estimatedDML are presented in table 7. No significant difference between the measured and estimated-DML was found. This indicated that both methods (directly measuring DML or calculating it by measuring $\mathrm{CO}_{2}$ ) determined similar DML values. It should be noted that there were larger differences among measured DML replicates (large standard errors, Fig. 2) than estimated DML replicates (Fig 4). Therefore, both methods can be used to predict the DML, but the prediction accuracy was low because of the large variation within replicates that was not predicted by either method.

\section{DISCUSSION}

Production of $\mathrm{CO}_{2}$ might be roughly related to DML (Steele et al. 1969) because 1) dry matter can be consumed by grain itself or infected fungi during their respiration. However, it should be noted that DML due to grain respiration is not significant as compared to the respiration of fungi unless grain kernels start to germinate (Hummel et al. 1954., Jian et al. 2014b); 2) Different substrates (dry maters) which have different respiration quotients might be used during the respiration and this would produce different amounts of $\mathrm{CO}_{2}$, and 3) grain might also absorb the produced $\mathrm{CO}_{2}$. This absorption depends on grain storage conditions and $\mathrm{CO}_{2}$ concentrations (Jian et al. 2014a). Our study found DML had a stronger relationship with germination and test weight at higher temperatures and moisture contents than that of lower temperatures and moisture contents. This conclusion is consistent with the three reasons mentioned above. However, regression equations had a low prediction accuracy (low $\mathrm{R}^{2}$ ). The zero DML mainly caused the low $\mathrm{R}^{2}$ after the germination, and test weight had already considerably decreased (Figs. 1 and 3). This was caused by the measurement method as small changes in the dry matter were hard to detect when canola was starting to spoil, and germination had already significantly decreased. The DML measured by weighing the mass loss requires a large sample. This measurement is not reliable when the DML is lower than $0.5 \%$ because of the error of the moisture content measurement and uneven distribution of moisture in a large sample. Therefore, germination and/or PTW can roughly estimate the DML trend but not calculate the DML value precisely.

Several studies have disputed the relevance of the storage time table that was developed using the DML threshold for shelled corn (Wilcke et al. 1993; Marin et al. 1999). Disagreement over the appropriateness of the $0.5 \%$ DML criterion has also been reported (Wilcke et al. 1993). Researchers showed that at $0.5 \%$ DML, corn can drop one to three grades (Friday et al. 1989). After the U.S. Grade No. 1 or No. 2 corn reaches $0.5 \%$ DML, the corn will be graded as the U.S. No. 4 or 5 (Wilcke et al. 1993). Corn with $25 \%$ moisture content at $30^{\circ} \mathrm{C}$ reaches $0.5 \% \mathrm{DML}$ in $7 \mathrm{~d}$ and could be unfit for use due to contamination by aflatoxins (Marin et al. 1999). However, Saul and Steele (1966) found the corn at $0.5 \%$ DML would have no more than $5 \%$ by mass of kernels with visible mould damage and would, therefore, not be graded lower than the U.S. No. 2. The mechanically damaged threshold of combined shelled corn is $30 \%$ (ASABE 2019), and allowable DML depends on the level of mechanical damage, temperature, and moisture content. It follows that 18 and $22 \%$ moisture corn at $20^{\circ} \mathrm{C}$ has an allowable DML of 0.5 and $0.2 \%$, respectively (Ng et al. 1998, Gupta et al. 1999). There are also disputes about DML of wheat, and researchers have argued that DML cannot be fully quantified using only respired $\mathrm{CO}_{2}$ as an indicator (Hall and Dean 1978; White et al. 1982b). Therefore, it is generally accepted that different types of grain should have different DML thresholds and that strict or overly low thresholds are not suitable as they will lead to high volumes of rejected grains and, in turn, result in increased economic impacts.

Grain that has suffered to certain DML would be at risk of developing grade reducing damage and mycotoxin production during subsequent storage (Marin et al. 1999). Our study found that canola had a germination less than $60 \%$ with a DML of zero. This particular canola was heavily infested by fungi (Sun et al. 2014; Jian et al. 2019a). Our study also found a significant variation in DML among different replicates. Even though the presence of moulds does not necessarily indicate the presence of mycotoxins because the mould species should have the toxigenic strain, heavy mould infestation would have a higher chance of mycotoxin production. In this study, we did not measure the mycotoxins. Mycotoxin production between Mouldy and Sound grain should be further studied. 
Grain mixing is a common practice in the industry and is an un-preventable outcome of loading and unloading, handling, transportation, turning, and coring of grains. Our study found that mixing sound kernels with mouldy canola speed up the deterioration of sound kernels. Fast multiplication of fungi in stored Mouldy canola resulted in rapid spoilage (Christensen and Meronuck 1989; Sun et al. 2014). Therefore, mixing sound grain with mouldy grain, even mouldy grain with a zero DML, should be avoided because zero DML canola might already have low germination caused by mould infection.

The DML value measured in this laboratory study might differ from that of grain stored in bins because the grain in bins is usually not stored at constant temperatures and moisture contents, and the spoilage might take a longer or shorter time. The conditions measured in this study are also not the recommended safe storage conditions for canola (Sun et al. 2014). These different storage conditions and spoilage periods might result in different DML values. Therefore, the relationship between germination, bulk density, and DML under storage conditions should be further investigated.

\section{CONCLUSION}

This study measured dry mass loss of Sound canola and Mouldy canola (Sound + Mouldy canola) at 25, 30, and $35^{\circ} \mathrm{C}$ over 14 weeks by weighing $10 \mathrm{~kg}$ samples every two weeks. We examined the relationship among the DML measured gravimetrically, germination decrease rate (GDR), and decrease in the percentage of test weight (PTW). The measured DML was also compared with the DML estimated from the respired $\mathrm{CO}_{2}$. The measured DML increased as germination and test weight decreased. Even though there was a stronger correlation between germination and test weight at higher moisture contents and temperatures, a decrease of germination and/or PTW did not predict the DML value with high accuracy. Measuring the mass loss or $\mathrm{CO}_{2}$ production roughly estimated DML but using DML to evaluate grain quality was unreliable. The Mouldy canola had a greater DML and GDR than the Sound canola at the same storage condition and in the same storage period.

\section{ACKNOWLEDGEMENT}

We thank the Natural Sciences and Engineering Research Council of Canada for partial funding of this study and the Canada Foundation for Innovation, Manitoba Research Innovation Fund, and several other partners for creating research infrastructure.

\section{REFERENCES}

ASABE. 2016a. Moisture Measurement -Unground Grain and Seeds, ASABE Standard. American Society of Agricultural and Biological Engineers, St. Joseph, MI.

ASABE. 2016b. ASAE D245.6 OCT2007. Moisture Relationships of Plant-based Agricultural Products, ASABE Standard. American Society of Agricultural and Biological Engineers, St. Joseph, MI.
ASABE. 2019. ASAE D535 MAY2005 (R2019) Shelled Corn Storage Time for $0.5 \%$ Dry Matter Loss, ASABE Standard. American Society of Agricultural and Biological Engineers, St. Joseph, Ml.

Bern, C. J., J. L. Steele, and R. V. Morey. 2002. Shelled corn $\mathrm{CO}_{2}$ evolution and storage time for $0.5 \%$ dry matter loss. Applied Engineering in Agriculture 18: 703-706. https://doi.org/10.13031/2013.11325

Brooker, D. B., F. W. Bakker-Arkema, and C. W. Hall. 1992. Drying and Storage of Cereal Grains and Oilseeds, Springer US, New York.

Canadian Grain Commission. 2019. Official grain grading guide. Canada Grain Commission.

Christensen, C. M., and R. A. Meronuck. 1989. Dry matter loss in yellow dent corn resulting from invasion by storage fungi. Plant Disease 73: 501-503. https://doi.org/10.1094/PD-73-0501

FAO. 2011. Global food losses and food waste - Extent, causes and prevention, pp. 29. Food and Agricultural Organization of the United Nations, Rome, Italy.

Friday, D. C., J. Tuite, and R. Stroshine. 1989. Effect of hybrid and physical damage on mould development and carbon dioxide production during storage of high moisture shelled corn. Cereal Chemistry 66: 422-426.

Gao, Y., J. Yang, S. Lan, H. Zhang, S. Wang, and L. Chen. 1998. Effects of temperature on rice quality and mass loss, pp. 1413-1421. In Proceedings of the 7th International Working Conference on Stored-product Protection, Sichuan Publishing House of Science and Technology, Chengdu, China.

Gupta, P., W. F. Wilcke, R. V. Morey, and R. A. Meronuck. 1999. Effect of dry matter loss on corn quality. Applied Engineering in Agriculture 15: 501-507. https://doi.org/10.13031/2013.5810

Hall, C. W., and P. E. Dean. 1978. Storage and preservation of cereal grains, In Cereals 78: Better Nutrition for the Worlds Millions, ed. Y. Pomeranz, 223-243. American Association of Cereal Chemists, Eagan, Minnesota.

Hummel, B. C. W., L. S. Cuendet, C. M. Christensen, and W. F. Geddes. 1954. Grain storage studies XIII. Comparative changes in respiration, viability, and chemical composition of mould-free and mouldcontaminated wheat upon storage. Cereal Chemistry 31: 143-150.

Jian, F., D. S. Jayas, N. D. G. White, and P. G. Fields. 2014a. Carbon dioxide sorption by stored canola under different storage conditions. Journal of Stored Products Research 59: 101-107. https://doi.org/10.1016/j.jspr.2014.05.009

Jian, F., P. Tang, M. A. A. Mamun, and D. S. Jayas. 2019a. Effect of field treatment on microfloral respiration and storability of canola under different storage conditions. American Journal of Plant Sciences 10: 1989-2001. https://doi.org/10.4236/ajps.2019.1011139 
Jian, F., V. Chelladurai, D. S. Jayas, C. J. Demianyk, and N. D. G. White. 2014b. Interstitial concentrations of carbon dioxide and oxygen in stored canola, soybean, and wheat seeds under various conditions. Journal of Stored Products Research 57: 63-72.

https://doi.org/10.1016/j.jspr.2013.12.002

Jian, F., M. A. A. Mamun, N. D. G. White, D. S. Jayas, P. G. Fields, and J. McCombe. 2019b. Safe storage times of FINOLA ${ }^{\circledR}$ hemp (Cannabis sativa) seeds with dockage. Journal of Stored Products Research 83: 3443. https://doi.org/10.1016/j.jspr.2019.05.013

Marin, S., V. Homedes, V. Sanchis, A. J. Ramos, and N. Magan. 1999. Impact of Fusarium moniliforme and $F$. proliferatum colonisation of maize on calorific losses and fumonisin production under different environmental conditions. Journal of Stored Products Research 35: $15-$ 26. https://doi.org/10.1016/S0022-474X(98)00026-5

Mills, J. T., and R. N. Sinha. 1980. Safe storage periods of farm stored rapeseed based on mycological and biochemical assessment. Postharvest Pathology and Mycotoxins 70: 541-547. https://doi.org/10.1094/Phyto70-541

Ng, H. F., W. F. Wilcke, R. V. Morey, R. A. Meronouk, and J. P. Lang. 1998. Mechanical damage and corn storability. Transactions of the ASAE 41: 1095-1100. https://doi.org/10.13031/2013.17239

Pronyk, C., D. Abramson, W. E. Muir, and N. D. G. White. 2006. Correlation of total ergosterol levels in stored canola with fungal deterioration. Journal of Stored Products Research 42: 162-172.

https://doi.org/10.1016/j.jspr.2004.12.004
Saul, R. A., and J. L. Steele. 1966. Why damaged shelled corn costs more to dry? Agricultural Engineering 47: 326-329.

Seitz, L. M., D. B. Sauer, and H. E. Mohr. 1982. Storage of high-moisture corn: fungal growth and dry matter loss. Cereal Chemistry 59: 100-105.

Steele, J. L., A. Saul, and W. V. Hukill. 1969. Deterioration of shelled corn as measured by carbon dioxide production. Transactions of the ASAE 12: 685-689. https://doi.org/10.13031/2013.38928

Sukabdi, A. 1979. Deterioration of rough rice as measured by carbon dioxide prediction. Unpublished MSc thesis. Manhattan, Kansas: Kansas State University.

Sun, K., F. Jian, D. S. Jayas, and N. D. G. White. 2014. Quality changes in high and low oil content canola during storage: part I - Safe storage time under constant temperatures. Journal of Stored Products Research 59: 320-327. https://doi.org/10.1016/j.jspr.2014.05.008

White, N. D. G., R. N. Sinha, and W. E. Muir. 1982a. Intergranular carbon dioxide as an indicator of biological activity associated with the spoilage of stored wheat. Canadian Agricultural Engineering 24: 35-42.

White, N. D. G., R. N. Sinha, and W. E. Muir. 1982b. Rapid determination of seed germination potential to measure quality loss in stored wheat. Canadian Journal of Plant Science 62: 1045-1048. https://doi.org/10.4141/cjps82155

Wilcke, W. F., R. A. Meronuck, R. V. Morey, H. F. Ng, J. P. Lang, and D. Jiang. 1993. Storage life of shelled corn treated with a fungicide. Transactions of the ASAE 36: 1847-1854. https://doi.org/10.13031/2013.28532 